\title{
Impact of Environmental Investments and Air Protection Costs on the Sustainable Development of Coal Mining Regions
}

\author{
Elena Morozova ${ }^{1}$, Anatoly Akulov ${ }^{1, *}$, and Timur Logunov ${ }^{2}$ \\ ${ }^{1}$ Kemerovo State University, I.P. Povarich Department of Management, 650043 Ulitsa Krasnaya 6, \\ Kemerovo, Russia \\ ${ }^{2}$ Kemerovo State University, Department of Foreign Languages in Professional Communication, \\ 650043 Ulitsa Krasnaya, 6 Kemerovo, Russia
}

\begin{abstract}
The transition to sustainable development of mining regions depends on the size and effectiveness of environmental investments. This study examines the impact of investments and current costs of air protection on the amount of air emissions from stationary sources. We used data on investments in atmospheric air protection, current costs of air protection, and amounts of air emission in 12 mining regions of Russia. The impact of investment and emission costs was simulated using standard pairwise regression equations and the Almon distributed lag model. The statistical insignificance of the models has been established, both in terms of the form of coupling equation and the significance of most coefficients with explanatory variables. The distributed lag model using data on investments in air protection over five years is also statistically insignificant. The paper also discusses the impact of investments and current costs on the specific emission amount per 1 ruble of the gross regional product. The model of pairwise linear regression and other possible forms of the coupling equation in this case are statistically insignificant. The study found that investments and current costs do not affect emissions from stationary sources. This suggests a lack of investments in the air protection and a low efficiency of their use.
\end{abstract}

\section{1 introduction}

Movement towards the sustainable development trajectory is one of the strategic goals of mining regions as specialization in the production of mineral resources is associated with high environmental risks and significant negative externalities. Investments and current costs of environmental protection and various environmental measures are traditionally considered among the main factors increasing the degree of sustainability of development. The said factor of improving the mining regions' sustainability can often be found in strategic planning documents.

\footnotetext{
* Corresponding author: akuanatolij@yandex.ru
} 
However, the impact of environmental protection costs on the magnitude of environmental damage and the degree of sustainability of development is still understudied. This makes it difficult to understand the interrelationships in the system of "environmental investments - the condition of the environment" and does not allow justifying the effectiveness of corporate and budgetary expenses. Therefore, more research is needed to identify the relationship between the cost of environmental protection and the degree of sustainability of mining regions' development.

\section{Materials and Methods}

Various aspects of the implementation of environmental ("green") investments have been studied since the early 2000s. According to R. Heinkel et al., the propensity for green investments is explained by the rising cost of capital for corporations whose activities are perceived as unethical and non-environmentally friendly. These incentives arise when the "green" investors encouraging the corporation to increase environmental friendliness become holders of more than $20 \%$ of the capital [1]. E. Agliardi et al. studied the peculiarities of "green" bonds. In particular, the difference in yields of straight and "green" bonds is statistically significant and can be explained by the increase in the issuer's credit quality. However, primary emissions of "green" bonds still require government support, which will allow for the formation of relatively cheap sources of funding environmental projects [2]. The specific market perception of "green" bonds was confirmed in a study by V. Baulkaran [3].

The work of D. Brodback et al. shows that "green" investing is influenced by altruistic motives. Therefore, the amount of environmental investments is determined by the degree of corporate social responsibility of managers and owners [4]. Wang et al. note the potential of China's state environmental policy in managing environmental damage. After the adoption of the Green Lending Rules financial and credit organizations sharply reduced investments in enterprises which cause high environmental damage [5].

Another research area is related to the direct evaluation of the motives and incentives for "green" investments, especially in terms of creating a low-carbon economy with minimal emissions of carbon oxides. Ganda et al. observe that incentives to corporate environmental investment are usually both limitations from the part of the government's environmental policy and concern about corporate image plus striving to master the "green" market segments with high sales margins [6]. For example, an important incentive for environmental investment is the willingness of consumers to overpay for goods whose production has not harmed the environment [7].

Thus, the majority of studies focus on the factors of "green" investments and the financial and economic efficiency of their implementation. W. Karpa justifies the positive impact of the introduction of green technology on reducing the damage to the people's health in developing countries. Low carbon technologies in energy industry are effective in combating mortality caused by climate change, and therefore, require strongest support [8].

The study by A.J. Tanentzap et al. demonstrates the positive impact of environmental investment in the agricultural sector. In particular, investment in reducing fertilizer use leads to a reduction in nitrogen oxide emissions and an increase in bird populations in agricultural land [9]. N. Pascal et al. consider an option of investing in the conservation of coral reef biodiversity, which will secure reef biodiversity together with an internal rate of return of $8.5 \%[10]$.

The efficiency of environmental investments in Russia is not being studied enough. Special studies are needed to determine the impact of environmental investments and costs on reducing environmental damage. This is an important feature of sustainable development as it is directly reflected in the genuine savings indicator. 
This paper examines the relationship between air protection costs (including investments and current costs) and environmental damage in the form of air emissions of pollutants. This is due to the fact that the mining industry has the greatest negative impact on the atmospheric air.

\section{Results and discussion}

The study uses the official data of the Federal State Statistics Service of the Russian Federation available in the statistical compendiums "Regions of Russia. Socio-economic Indicators. 2018" (http://www.gks.ru/bgd/regl/b18_14p/Main.htm), "Environmental Protection in Russia. 2016" (http://www.gks.ru/bgd/regl/b16_54/Main.htm), "Environmental Protection in Russia. - 2018" (http://www.gks.ru/bgd/regl/b18_54/Main.htm). The following data was borrowed from these sources: the amount of air emissions from stationary sources, investment in fixed assets aimed at environmental protection and rational use of natural resources (atmospheric air protection), current costs of environmental protection (atmospheric air protection and climate change mitigation), and gross regional product (GRP).

When modeling the impact of environmental investment and protection costs, correlation and regression analysis and the method of least squares were used to obtain explicative models. Besides, given the effect of environmental investments is distributed in time, the model with a distributed lag was used, in particular, S. Almon's lag model (2):

$$
x_{t}=\mu+\sum_{j=0}^{q} \alpha_{j} z_{t-j}+\varepsilon_{t}=\mu+\alpha(L) z_{t}+\varepsilon_{t}
$$

where $x_{t}$ is the variable to be studied; $\mu$ is the free term, $\alpha_{i}$ is the sum of the values of the pulse response function; $z$ is the explanatory factor; $\varepsilon_{t}$ is white noise.

In this case, the parameter $\alpha_{i}$ is calculated as (2):

$$
a_{i}=\sum_{s=0}^{p} \gamma_{s} j^{s}, \quad j=0, \ldots, q
$$

where $j$ is the lag magnitude, $p$ is the degree of the polynomial, $\gamma$ is the rate of response $a_{i}$ to the change in $z$.

To build a model with a time lag, the "Statistica 13.0" software was used, all other calculations were done using the analysis package in Microsoft Excel.

At the first stage of the study, the regression equations were constructed reflecting the dependence of air emissions on investments in atmospheric air protection in the same year, and current costs of atmospheric air protection. Quality characteristics of the equations are presented in Tables 1 and 2 .

Table 1. Quality estimates for the pairwise linear regression equation (dependent variable is air emissions from stationary sources; explanatory variable is investments in air protection in a certain year).

\begin{tabular}{|l|c|c|c|c|c|c|c|c|}
\hline & $\begin{array}{c}\text { Explanatory } \\
\text { variable }\end{array}$ & $\begin{array}{c}\text { Free } \\
\text { term }\end{array}$ & t-test & F-test & Elasticity & $\begin{array}{c}\text { Beta } \\
\text { coefficient }\end{array}$ & $\begin{array}{c}\text { Approx. } \\
\text { error }\end{array}$ & $\mathbf{R}^{2}$ \\
\hline $\begin{array}{l}\text { Equation } \\
\text { estimates }\end{array}$ & 0.29 & 195.64 & 1.74 & 3.03 & 0.63 & 0.48 & $257.9 \%$ & 0.23 \\
\hline $\begin{array}{l}\text { Reference } \\
\text { value }\end{array}$ & & & 2.23 & 4.96 & 1.00 & - & $7.0 \%$ & - \\
\hline
\end{tabular}


Table 2. Quality estimates for the pairwise linear regression equation (dependent variable is air emissions from stationary sources, explanatory variable is current costs of air protection).

\begin{tabular}{|l|c|c|c|c|c|c|c|c|}
\hline & $\begin{array}{c}\text { Explanator } \\
\mathbf{y} \text { variable }\end{array}$ & $\begin{array}{c}\text { Free } \\
\text { term }\end{array}$ & t-test & F-test & $\begin{array}{c}\text { Elasticit } \\
\mathbf{y}\end{array}$ & $\begin{array}{c}\text { Beta } \\
\text { coefficient }\end{array}$ & $\begin{array}{c}\text { Approx. } \\
\text { error }\end{array}$ & $\mathbf{R}^{\mathbf{2}}$ \\
\hline $\begin{array}{l}\text { Equation } \\
\text { estimates }\end{array}$ & 0.32 & -2.92 & 12.86 & 165.4 & 1.01 & 0.97 & $46.9 \%$ & 94.3 \\
\hline $\begin{array}{l}\text { Reference } \\
\text { value }\end{array}$ & & & 2.23 & 4.96 & 1.00 & - & $7.0 \%$ & - \\
\hline
\end{tabular}

The data in Tables 1-2 show the absence of the impact of investments in atmospheric air protection and current costs of air protection on the amount of pollutant emissions into the air from stationary sources. The equations of pairwise regression are not statistically significant. In particular, the regression equation making air emissions in a certain year contingent on investments in air protection in the same year can show that the growth of investments results even in an increase in emissions. However, the form of the equation itself and its coefficients are statistically insignificant. This is indicated by the values of Student's t-test, Fisher's test, and coefficient of determination. The pairwise regression equation is unsuitable for explaining the differentiation of emissions among mining regions by differences in the amount of investments in air protection.

Formally, the second equation of pairwise regression has a slightly higher quality, which makes the amount of air emissions dependent on current costs (see Table 2). The coefficient of this equation is statistically significant. There is a rather high coefficient of determination. However, the level of approximation error does not allow using this regression equation as an explanation of the effect of current costs on the air protection based on the amount of air emissions. The parameters of the model are statistically insignificant. At the same time, it should be borne in mind that the form of the regression equation itself is significant. It also indicates a positive relationship between emissions and current costs. The multiple regression equation was not built in the study, because it is impractical to further consider the simultaneous impact of investments and current costs on the air protection based on the amount of air emissions.

Therefore, investments and current costs in the mining regions of Russia do not have a positive impact on reducing air emissions of pollutants from stationary sources. In addition, there are weak but positive values of the correlation coefficients between these indicators. Thus, the higher the level of current costs and investments, the higher level of air emissions in the region can be. The explanation of this fact is that at a high level of emissions and a generally extremely low level of costs and investment in the air protection decisions are made with a view to at least partially compensate for the accumulated damage. Environmental managers provide a region with a certain compensation for air pollution and conduct one-off activities to address the most pressing environmental problems. However, a significant reduction in emissions cannot occur, since the absolute amount of environmental costs and investment is extremely small.

Also, the lack of a positive relationship between investments, costs and emissions can be explained by a rather low efficiency of environmental measures themselves, the use of outdated technological solutions, and a wrong choice of environmental priorities in terms of minimizing damage. If the relationship of emissions with environmental investments can be mediated with a time lag, current costs should produce results in the same period. As this does not happen, the existing model of compensation for environmental damage should be recognized as limited. It does not meet the requirements of sustainable development and needs to be adjusted.

However, interregional differentiation of environmental protection costs can potentially be associated with varying degrees of environmental pollution per 1 ruble of GRP. To test this hypothesis, we considered the effect of current costs and investments in the protection 
of atmospheric air on the metric, which can be named as "specific emissions into the atmosphere per 1 million rubles of GRP". This magnitude is determined by dividing the mass of air emissions from stationary sources by the nominal value of GRP and is measured in tons of emissions per 1 million rubles of GRP. Tables 3-4 present estimates for the regression equations that make specific air emissions per 1 ruble of GRP contingent on investments in the air protection and current costs of air protection, respectively. A modification of the analysis technique using the specific amount of emissions per GRP unit as a pollution measure does not any reveal dependence either.

The pairwise regression equation, where the explanatory variable is investment in the air protection in a certain year, is not statistically significant either by the type of equation or by the coefficient of the explanatory variable. This is indicated by the values of the Fisher's test and t-test criteria, which are below those from the reference table. In addition, the approximation error is very high and the coefficient of determination is low. For the second equation, the t-test value is above the one from the table. This indicates the significance of the coefficient with the explanatory variable, however, the coefficient itself is extremely small. The form of the regression equation is statistically insignificant, since the approximation error is very high and the coefficient of determination is extremely low.

Thus, investments in and current costs of the protection of atmospheric air do not affect the differentiation of specific emissions per GRP unit among the mining regions of Russia. Specific emissions depend, first of all, on the availability of enterprises extracting minerals in open-pits, as well as on greenhouse gas emissions. In oil-producing regions, their value is somewhat lower, since the production of hydrocarbons causes less pollution of the atmosphere. Equations of other types, in particular, a second-order polynomial, also fail to reveal dependencies between the factors considered in the study. This may indicate an insufficient total amount of costs of the air protection, as well as a low efficiency of environmental measures.

Table 3. Quality estimates for the pairwise linear regression equation (dependent variable is specific air emissions per 1 ruble of GRP, explanatory variable is investments in air protection in a certain year).

\begin{tabular}{|l|c|c|c|c|c|c|c|c|}
\hline & $\begin{array}{c}\text { Explanatory } \\
\text { variable }\end{array}$ & $\begin{array}{c}\text { Free } \\
\text { term }\end{array}$ & t-test & F-test & Elasticity & $\begin{array}{c}\text { Beta } \\
\text { coefficient }\end{array}$ & $\begin{array}{c}\text { Approx. } \\
\text { error }\end{array}$ & $\mathbf{R}^{\mathbf{2}}$ \\
\hline $\begin{array}{l}\text { Equation } \\
\text { estimates }\end{array}$ & 0.000164 & 0.28 & 1.64 & 4.28 & 0.41 & 0.55 & $60.2 \%$ & 0.30 \\
\hline $\begin{array}{l}\text { Reference } \\
\text { value }\end{array}$ & & & 2.23 & 4.96 & 1.00 & - & $7.0 \%$ & - \\
\hline
\end{tabular}

Table 4. Quality estimates for the pairwise linear regression equation (the dependent variable is specific air emissions per 1 ruble of GRP, explanatory variable is current costs of air protection).

\begin{tabular}{|l|c|c|c|c|c|c|c|c|}
\hline & $\begin{array}{c}\text { Explanatory } \\
\text { variable }\end{array}$ & $\begin{array}{c}\text { Free } \\
\text { term }\end{array}$ & t-test & F-test & Elasticity & $\begin{array}{c}\text { Beta } \\
\text { coefficient }\end{array}$ & $\begin{array}{c}\text { Approx. } \\
\text { error }\end{array}$ & $\mathbf{R}^{2}$ \\
\hline $\begin{array}{l}\text { Equation } \\
\text { estimates }\end{array}$ & $4.2^{-10}-5$ & 0.40 & 3.02 & 0.06 & 0.15 & 0.25 & $65.6 \%$ & 0.06 \\
\hline $\begin{array}{l}\text { Reference } \\
\text { value }\end{array}$ & & & 2.23 & 4.96 & 1.00 & - & $7.0 \%$ & - \\
\hline
\end{tabular}

However, environmental investments may have a time lag. The effect of investing in the protection of atmospheric air and reducing greenhouse gas emissions can manifest itself in 2-3 years. Therefore, the study also considered a model with a time lag. Model estimates are presented in Tables 5-6. As can be seen from the data in Tables 5-6, even given the time lag, there is no relationship between investments in air protection and the reduction in greenhouse gases, on the one hand, and the actual amount of air emissions from stationary sources, on the other. 
Table 5. The results of the analysis of the model variance with a time lag between investments and the volume of emissions (data obtained with "Statistica 13.0" software).

\begin{tabular}{|l|l|l|l|l|}
\hline & Sum of squares & Degrees of freedom & F-statistic & P-statistic \\
\hline Coefficient & 5912365 & 2 & 9.414598 & 0.006221 \\
\hline Form of equation & 2825999 & 9 & & \\
\hline Total & 8738364 & & & \\
\hline
\end{tabular}

Table 6. Estimation of the regression coefficients of the model with a time lag between investments and the volume of emissions (data obtained with "Statistica 13.0" software).

\begin{tabular}{|l|l|l|l|}
\hline Regression coefficient & Standard error & T-statistic & p-statistic \\
\hline 0,265243829445 & 0.131459652096 & 2.017682423596 & 0.074399853730 \\
\hline 0,246817246896 & 0.131484501885 & 1.877158473861 & 0.093228075540 \\
\hline
\end{tabular}

The efforts that have been made so far have not led to a significant reduction in environmental damage. The current mechanism of commercial environmental management and environmental investments is not yet capable of bringing the mining regions of Russia closer to the sustainable development trajectory.

\section{Conclusion}

The pilot quantitative study showed that there are no statistically significant causal relationships between investments in and costs of air protection, on the one hand, and emissions from stationary sources, on the other. An increase in the absolute value of investments in the air protection does not lead to a reduction in emissions either in a certain year, or within relevant time lags. The specific volume of air emissions from stationary sources per 1 million rubles of GRP is not dependent on current costs of and investments in air protection either.

The lack of relationship is due to the low absolute volume of investments in relation to the total volume of investments in fixed capital, the existing level of air emissions, and a low efficiency of the environmental measures implemented. It is necessary to increase the efficiency of the environmental and economic mechanism of air protection, taking into account the potential for reducing emissions per unit of costs or investments.

Prospects for further research are related to the study of longer time series at the regional level, since in individual territories a variation in investment efficiency and costs of the air protection is possible. In addition, it is advisable that the set of metrics should be expanded with those indirectly related to sustainable development due to the reduction in air pollution. In particular, additional indicators can include the amount of air emissions of pollutants from stationary sources per capita, as well as the incidence rate associated with a poor condition of atmospheric air. This will allow a more comprehensive evaluation of both the environmental and social effects of investments in air protection and sustainable development.

\section{References}

1. R. Heinkel, A. Kraus, J. Zechner, J. of Fin. and Quant. Analys. 36, 4 (2001)

2. E. Agliardi, R. Agliardi, Envir. and Devel. Econ. 16, 3 (2019)

3. V. Baulkaran, J. of Asset Manag. 20, 1 (2019)

4. D. Brodback, N. Guenster, D. Mezger, Rev. of Fin. Econ. 37, 1 (2019)

5. E. Wang, X. Liu, J. Wu, D. Cai, Sustain. 11, 3 (2019)

6. F. Ganda, C. Ngwakwe, C. Ambe, Envir. Econ. 6, 1 (2015) 
7. X. Gao, H. Zheng, Inter. J. of Envir. Res. and Pub. Health. 14, 12 (2017)

8. W. Karpa, J. of Innov. Econ. \& Manag. 3, 24 (2017)

9. A. Tanentzap, A. Lamb, S. Walker, A. Farmer, PLOS Biol. 13, 9 (2015)

10. N. Pascal, A. Brathwaite, M. Philip, W. Melissa, Duke Envir. Law \& Pol. For. 38 (2018) 